NBER WORKING PAPER SERIES

\title{
INTERNATIONAL FINANCIAL INTEGRATION AND ECONOMIC GROWTH
}

\author{
Hali J. Edison \\ Ross Levine \\ Luca Ricci \\ Torsten Sløk
}

Working Paper 9164

http://www.nber.org/papers/w9164

\section{NATIONAL BUREAU OF ECONOMIC RESEARCH \\ 1050 Massachusetts Avenue \\ Cambridge, MA 02138 \\ September 2002}

The views expressed herein are those of the authors and not necessarily those of the National Bureau of Economic Research.

(C) 2002 by Hali J. Edison, Ross Levine, Luca Ricci, and Torsten Sløk. All rights reserved. Short sections of text, not to exceed two paragraphs, may be quoted without explicit permission provided that full credit, including (C) notice, is given to the source. 
International Financial Integration and Economic Growth

Hali J. Edison, Ross Levine, Luca Ricci and Torsten Sløk

NBER Working Paper No. 9164

September 2002

JEL No. F3, O4, O16

\begin{abstract}
$\underline{\text { ABSTRACT }}$
This paper uses new data and new econometric techniques to investigate the impact of international financial integration on economic growth and also to assess whether this relationship depends on the level of economic development, financial development, legal system development, government corruption, and macroeconomic policies. Using a wide array of measures of international financial integration on 57 countries and an assortment of statistical methodologies, we are unable to reject the null hypothesis that international financial integration does not accelerate economic growth even when controlling for particular economic, financial, institutional, and policy characteristics.
\end{abstract}

Hali J. Edison

International Monetary Fund

Washington, DC 20431

hedison@imf.org

Luca Ricci

International Monetary Fund

Washington, DC 20431
Ross Levine

Finance Department

University of Minnesota

Minneapolis, MN 55455

Torsten Sløk

International Monetary Fund

Washington, DC 20431 


\section{Introduction}

Theory provides conflicting predictions about the growth effects of international financial integration (IFI), i.e., the degree to which an economy does not restrict cross-border transactions. According to some theories, IFI facilitates risk-sharing and thereby enhances production specialization, capital allocation, and economic growth (Obstfeld, 1994; Acemoglu and Zilibotti, 1997). Further, in the standard neoclassical growth model, IFI eases the flow of capital to capitalscarce countries with positive output effects. Also, IFI may enhance the functioning of domestic financial systems, through the intensification of competition and the importation of financial services, with positive growth effects (Klein and Olivei, 2000; Levine, 2001). On the other hand, IFI in the presence of pre-existing distortions can actually retard growth. ${ }^{1}$ Boyd and Smith (1992), for instance, show that IFI in countries with weak institutions and policies - e.g., weak financial and legal systems - may actually induce a capital outflow from capital-scarce countries to capitalabundant countries with better institutions. Thus, some theories predict that international financial integration will promote growth only in countries with sound institutions and good policies.

Although theoretical disputes and the concomitant policy debate over the growth effects of IFI have produced a burgeoning empirical literature, resolving this issue is complicated by the difficulty in measuring IFI. Countries impose a complex array of price and quantity controls on a broad assortment of financial transactions. Thus, researchers face enormous hurdles in measuring cross-country differences in the nature, intensity, and effectiveness of barriers to international capital flows (Eichengreen, 2001).

\footnotetext{
${ }^{1}$ To paraphrase Eichengreen's (2001, p.1) insightful literature review, there are innumerable constellations of distortions for which liberalization of international capital controls will hurt resource allocation and growth. For example, in the presence of trade distortions, capital account liberalization may induce capital inflows to sectors in which the country has a comparative disadvantage.
} 
In practice, empirical analyses use either (i) proxies for government restrictions on capital flows or (ii) measures of actual international capital flows. The International Monetary Fund's (IMF) IMF-restriction measure is the most commonly used proxy of government restrictions on international financial transactions. It classifies countries on an annual basis by the presence or absence of restrictions, i.e., it is a zero-one dummy variable. Quinn (1997) attempts to improve upon the IMF-restriction measure by reading through the IMF's narrative descriptions of capital account restrictions and assigning scores of the intensity of capital restrictions. Unfortunately, the Quinn (1997) measure is only available for intermittent years for most countries $(1958,1973,1982$, and 1988). The advantage of the IMF-Restriction and Quinn (1997) measures is that they proxy directly for government impediments. The disadvantage of both measures, as noted above, stems from the difficulty in accurately gauging the magnitude and effectiveness of government restrictions.

Empirical studies also use measures of actual international capital flows to proxy for international financial openness. The assumption is that more capital flows as a share of Gross Domestic Product (GDP) are a signal of greater IFI. The advantage of these measures is that they are widely available and they are not subjective measures of capital restrictions. A disadvantage is that many factors influence capital flows. Indeed, growth may influence capital flows and policy changes may influence both growth and capital flows, producing a spurious, positive relationship between growth and capital flows, and growth may affect capital flows. This highlights the need to account for possible endogeneity in assessing the growth IFI-relationship.

Empirical evidence yields conflicting conclusions about the growth effects of IFI. Grilli and Milesi-Ferretti (1995), Rodrik (1998), and Kraay (1998) find no link between economic growth and the IMF-restriction measure. In contrast, Edwards (2001) finds that the IMF-restriction measure is 
negatively associated with growth in rich countries but positively associated with growth in poor countries. He thus argues that good institutions are necessary to enjoy the positive growth effects of IFI. Arteta, Eichengreen, and Wyplosz (2001), however, argue that Edwards's results are not robust to small changes in the econometric specification. While Quinn (1997) finds that his measure of capital account openness is positively linked with growth, Arteta, Eichengreen, and Wyplosz (2001) and Kraay (1998) find these results are not robust. Finally, while some studies find that foreign direct investment (FDI) inflows are positively associated with economic growth when countries are sufficiently rich (Blomstrom, Lipsey, and Zejan, 1994), educated (Borenzstein, De Gregorio, and Lee, 1998), or financially developed (Alfaro et al., 2001), Carkovic and Levine (2002) find that these results are not robust to controlling for simultaneity bias. ${ }^{2}$

In light of the current state of the literature on the growth effects of IFI, we contribute to existing empirical analyses in four ways.

First, we examine an extensive array of IFI indicators. We examine the IMF-restriction measure and the Quinn measure of capital account restrictions. Furthermore, we examine various measures of capital flows: FDI, portfolio, and total capital flows. Moreover, we consider measures of just capital inflows as well as measures of total capital flows (inflows plus outflows) to proxy for IFI because openness is defined both in terms of receiving foreign capital and in terms of domestic residents having the ability to diversity their investments abroad. We examine a wide array of IFI proxies because each indicator has advantages and disadvantages.

Second, we examine two new measures of IFI. Lane and Milesi-Ferretti (2002) carefully compute the accumulated stock of foreign assets and liabilities for an extensive sample of countries.

\footnotetext{
${ }^{2}$ For more detailed literature reviews of cross-country studies of the causes and effects of IFI, see Eichengreen (2001) and Edison, Klein, Ricci, and Sløk (2002). For a review of country-specific experiences with IFI, see Cooper (1999).
} 
Since we want to measure the average level of openness over an extended period of time, these stock measures provide a useful additional indicator. Furthermore, these stock measures are less sensitive to short-run fluctuations in capital flows associated with factors that are unrelated to IFI, and may therefore provide a more accurate indicator of IFI than capital flow measures. As proxies for IFI, we examine both the accumulated stock of liabilities (as a share of GDP) and the accumulated stock of liabilities and assets (as a share of GDP). Also, we break down the accumulated stocks of financial assets and liabilities into FDI, portfolio, and total financial claims in assessing the links between economic growth and a wide assortment of IFI indicators. Thus, we add these additional IFI indicators to the empirical examination of growth and international financial integration.

Third, since theory and some past empirical evidence suggest that IFI will only have positive growth effects under particular institutional and policy regimes, we examine an extensive array of interaction terms. Specifically, we examine whether IFI is positively associated with growth when countries have well-developed banks, well-developed stock markets, well functioning legal systems that protect the rule of law, low levels of government corruption, sufficiently high levels of real per capita GDP, high levels of educational attainment, prudent fiscal balances, and low inflation rates. Thus, we search for economic, financial, institutional, and policy conditions under which IFI boosts growth.

Fourth, we use newly developed panel techniques that control for (i) simultaneity bias, (ii) the bias induced by the standard practice of including lagged dependent variables in growth regressions, and (iii) the bias created by the omission of country-specific effects in empirical studies of the IFI-growth relationship. Since each of these econometric biases is a serious concern in assessing the growth-IFI nexus, applying panel techniques enhances the confidence we can have in 
the empirical results. Furthermore, the panel approach allows us to exploit the time-series dimension of the data instead of using purely cross-sectional estimators.

Before beginning the analyses, it is important to mention a related strand of the literature on IFI. We examine the relationship between broad measures of IFI and growth. Other researchers focus instead on a much narrower issue: restrictions on foreign participation in domestic equity markets. Levine and Zervos (1998b) construct indicators of restrictions on equity transactions by foreigners. They show that liberalizing restrictions boosts equity market liquidity. Henry (2000a,b) extends these data and shows that liberalizing restrictions on foreign equity flows boosts domestic stock prices and domestic investment. Bekaert, Harvey, and Lundblad (2001) go farther and show that easing restrictions on foreign participation in domestic stock exchanges accelerates economic growth. While it is valuable to examine the impact of liberalizing restrictions on foreign activity in domestic stock markets, it is also valuable to study whether international financial integration in general has an impact on economic growth under particular economic, financial, institutional, and policy environments. This paper examine the relationship between economic growth and broad measures of IFI for large cross-section of countries while recognizing the value of studies that focus on specific barriers to particular categories of international financial transactions.

The remainder of the paper is organized as follows. Section II discusses the data and presents summary statistics. Section III describes the econometric methodology while Section IV gives the results. Section V concludes.

\section{Data and Summary Statistics}

This paper uses new data to examine the growth effects of international financial integration (IFI) and to assess whether the growth-IFI relationship depends on the level of economic 
development, financial development, institutional development, or macroeconomic policies. Given existing barriers to measuring IFI confidently for a broad cross-section of countries, this paper seeks to improve the analysis of IFI and growth by (i) assessing a broader array of IFI indicators than any previous study and (ii) using a new type of financial openness indicator. The new indicators are based on the Lane and Milesi-Ferretti (2002) measures of the accumulated stock of foreign assets and liabilities.

\section{A. Data on International Financial Integration ${ }^{3}$}

IMF-Restriction: The IMF-Restriction measure equals one in years where there are restrictions on capital account transactions and zero in years where the are no restrictions on these external transactions. The data are from the IMF's Annual Report on Exchange Arrangements and Exchange Restrictions (AREAER) (line E.2). When conducting regressions averaged over, for example, the 1980-2000 period, we follow the literature and average the IMF-Restriction measure over the entire period and use this to measure the average level of openness during the period (e.g., see Grilli and Milesi-Ferretti, 1995; Rodrik, 1998; and Klein and Olivei, 2001). ${ }^{4}$ As emphasized above, the IMF-Restriction measure may not accurately capture the magnitude and effectiveness of restrictions on capital flows.

Quinn measure: Based on descriptive information in the in the AREAER, Quinn (1997) assigns scores associated of the intensity of official restrictions on both capital inflows and outflows. This measure attempts to improve upon the IMF-Restriction measure by providing

\footnotetext{
${ }^{3}$ The Data Appendix Data provides more detailed information on the variables used in this paper.

${ }^{4}$ In 1997, however, there was structural break in the AREAER documentation of capital controls. No longer are countries categorized as having open or restricted capital accounts. Since 1997, information is provided on thirteen separate categories of capital flows, including a distinction between restrictions on inflows and outflows. Because of the structural break, we only use information on IMF-Restriction through 1996.
} 
information about the magnitude of restrictions, rather than simply designating countries as closed or open. The Quinn measure, however, is a particularly subjective measure. Also, it is highly correlated (0.9) with the IMF-Restriction measure (Edison, Klein, Ricci, and Sløk, 2002).

Moreover, for non-OECD countries, it is only available for two years $(1982,1988)$ over the sample period that we examine. Thus, we cannot use the Quinn measure in our panel estimates. Since the use of panel estimates to reduce statistical biases is an important contribution of this paper, we confirm our pure cross-country, ordinary least squares (OLS) results using the Quinn measure but do not report these results in the tables.

Stock of Capital Flows accumulates FDI and portfolio inflows and outflows as a share of GDP. Thus, it is the stock of a nation's foreign assets plus liabilities as a share of GDP (Lane and Milesi-Ferretti, 2002). We examine assets plus liabilities because theoretical concepts of openness include both (i) the ability of foreigners to invest in a country and (ii) the ability of residents to invest abroad. We have also examined the components of the Stock of Capital Flows measures, i.e., the accumulated stock of FDI and portfolio flows respectively. Since we obtain the same results with these components, we focus on the stock of total capital inflows and outflows. This is the first time these stock measures of IFI have been used to study economic growth. The advantage of the stock measure is that it accumulates flows over a long period. Thus, unlike standard capital flow measures, the stock measure does not vary very much with short-run changes in the political and policy climate.

Flow of Capital equals FDI and portfolio inflows and outflows as a share of GDP. Thus, it is total capital inflows plus outflows divided by GDP. Kraay (1998) used this indicator to measure capital account openness. As noted, it is important to measure both inflows and outflows in creating an IFI proxy. As with the Stock of Capital Flows measure, we have examined the 
individual components of the Flow of Capital indicator. Specifically, we examined FDI and portfolio flows individually. Again, we obtain similar results with the sub-components, so we simply report the results with total capital flows. While we recognize the problems associated with using the Flow of Capital indicator, we include it to provide as comprehensive an empirical assessment of IFI and growth as possible.

Stock of Capital Inflows accumulates FDI and portfolio inflows as a share of GDP. Thus, it is the stock of a nation's foreign liabilities as a share of GDP (Lane and Milesi-Ferretti, 2002). Unlike the Stock of Capital Flows variable defined above, the Stock of Capital Inflows indicator excludes capital outflows. We use the Stock of Capital Inflows measure since some consider capital inflows to be particularly important for economic growth in developing countries. We have also examined the components of the Stock of Capital Inflows measures, i.e., the stock of FDI and portfolio liabilities respectively, but only report the results on the stock of total capital inflows because we get similar results on the components. Thus, we add this new measure of capital account openness to the study of growth and IFI.

Inflows of Capital equals FDI and portfolio inflows as a share of GDP. Unlike Flows of Capital, Inflows of Capital exclude capital outflows. Again, we include this variable since some discussions emphasize the growth effects of capital inflows. While none of these indicators may fully capture the concept of international financial integration, we use a collection of indicators with different pros and cons to assess the relationship between economic growth and financial openness.

\section{B. Data on Other Variables}

To assess the relationship between economic growth and IFI we control for other potential growth determinants and also examine whether IFI influences growth only under particular economic, financial, institutional, and policy environments (Levine and Renelt, 1992). Growth 
equals real per capita GDP growth, which is computed over the period of analysis. Thus, in the pure cross-country regressions and in the Table 1 summary statistics Growth is computed over the 1980-2000 period. As is common in cross-country growth regressions, we control for initial conditions. Initial Income equals the logarithm of real per capita GDP in the initial year of the period under consideration, and Initial Schooling equals the logarithm of the average years of secondary schooling in the initial year of the period under consideration. We examine both financial intermediary development and the liquidity of the domestic stock market. Private Credit equals the logarithm of credit to the private sector by deposit money banks and other financial institutions as a share of GDP, while Stock Activity equals the logarithm of the total value of domestic stock transactions on domestic exchanges as a share of GDP. We use logarithms to reduce the influence of large outliers of the finance variables. Including the finance variables in levels still produces a positive relationship between financial development and growth (Levine and Zervos, 1998a). We also control for macroeconomic policies. Inflation equals the growth rate of the consumer price index and Government Balance equals the governments fiscal balance divided by GDP, with positive values signifying a surplus and negative values a fiscal deficit. Finally, we examine the level of institutional development, as measured by the law and order tradition (Law and Order Tradition) of the country and the level of government corruption (Corruption in Government), where larger values signify better institutions, i.e., a better law and order tradition and less corruption.

\section{Summary Statistics}

Table 1 provides summary statistics. Four key points are worth emphasizing before we undertake a systematic examination of the IFI-growth relationship. 
First, rich countries tend to be more open. As shown in Table 1, Panel B, there is a significant positive correlation between Initial Income and Stock of Flows, Stock of Inflows, Flows of Capital, and Inflows of Capital. Similarly, these measures of IFI are also positively associated with Initial Schooling in 1980. The IMF-Restriction measure, however, is not significantly correlated with income or schooling. Rich, well-educated countries tend to be more open to international financial transactions, as measured by the stock and flow of capital flows, than poorer countries and countries with less well-educated workers.

Second, countries with well-developed financial intermediaries, stock markets, legal systems, and low levels of government corruption tend to have greater capital account openness. Specifically, Private Credit, Stock Activity, Law and Order, and Corruption are all positively associated with the measures of Stock of Capital Flows, Stock of Capital Inflows, Flows of Capital, and Inflows of Capital and negatively associated with the IMF-Restriction measure. Thus, while measures of IFI are generally unrelated to macroeconomic policies, as proxied by Inflation and the Government Balance, IFI is strongly correlated with measures of institutional and financial development.

Third, the IMF-Restriction measure is significantly, negatively correlated with the stock and flow measures of capital account openness. Specifically, countries that have had a large number of years over the post-1980 period with capital account restrictions (high values of the IMF-Restriction measure) have, on average, lower values of Stock of Capital Flows, Stock of Capital Inflows, Flows of Capital, and Inflows of Capital. Thus, measures of government restrictions on capital account transactions are negatively linked with international capital flows and the accumulated stock of those flows. 
Fourth, the correlations between economic growth and the indicators of IFI are mixed. The IMF-Restriction measure, Stock of Capital Flows, and Flows of Capital are not significantly correlated with economic growth at the 0.05 level. However, growth is significantly positively associated with Stock of Capital Inflows and Inflows of Capital. This suggests the value of examining a range of indicators and studying IFI indicators that focus on capital inflows.

\section{Methodology}

This section describes three econometric methods that we use to assess the relationship between IFI and economic growth. We first use simple ordinary least squares (OLS) regressions with one observation per country over the $1980-2000$ period. Second, we use a two-stage least squares instrumental variable estimator within the purely cross-country context, i.e., while using one observation per country over the $1980-2000$ period. Third, we use a generalized method of moments (GMM), dynamic panel procedure to control for potential biases associated with the purely cross-sectional estimators.

\section{A. OLS framework}

The pure cross-sectional, OLS analysis uses data averaged over 1980-2000, such that there is one observation per country, and heteroskedasticity-consistent standard errors. The basic regression takes the form:

$$
\text { GROWTH }=\alpha+\beta I F I+\gamma^{c} X+\varepsilon_{i},
$$

where the dependent variable, GROWTH, equals real per capita GDP growth, IFI is one of the five measures of international financial integration discussed above, and $\mathrm{X}$ represents a matrix of control variables. We focus on the 1980-2000 period because we have complete data for the 57 countries over this period. When using data in 1960s and 1970s, some countries are missing data 
over certain periods. Twenty years of data allows us to abstract from business-cycle fluctuations and short-run political and financial shocks and focus on long-run growth. Thus, as discussed in the Introduction, some theories suggest that greater international financial integration will be positively associated with economic growth, i.e., these theories predict that $\beta$ will be significantly greater than zero.

We also use a slight variant of equation (1) to examine whether IFI influences growth only under certain economic, institutional, and policy conditions. Specifically, we also examine the following regression equation with interaction terms.

$$
\mathrm{GROWTH}=\alpha+\beta I F I+\delta\left[I F I^{*} x\right]+\gamma^{6} X+\varepsilon_{i},
$$

where $\mathrm{x}$ is a variable included in the matrix of control variables $\mathrm{X}$. For example, if $\mathrm{x}$ is the Rule of Law, equation ( $\left.1^{\prime}\right)$ permits us to assess whether international financial integration has a different influence on growth in countries with high values of the Rule of Law than in countries with low values of the Rule Law. Specifically, differentiate equation (1') with respect to IFI to obtain,

$$
\partial \mathrm{GROWTH} / \partial \mathrm{IFI}=\beta+\delta^{*} \mathrm{x}
$$

If $\delta>0$, this would imply that greater international financial integration has a bigger, positive growth effect in countries with high levels of $x$. Thus, for example, the theoretical model developed by Boyd and Smith (1992) predicts that IFI will positively influence economic performance only in countries with high levels of the Rule of Law and well-developed financial systems. This model, therefore, predicts that when $\mathrm{x}$ is the Rule of Law or a measure of financial development that $\delta$ will be greater than zero. We examine many "x"”s, i.e., we examine many possible economic, institutional, and policy conditions that may influence the IFI-growth relationship. 


\section{B. Two-Stage Least Squares}

We also use a two-stage least squares instrumental variable estimator to control for simultaneity bias while allowing for heteroskedasticity-consistent errors. It uses the same countries, estimation period, and equation specification as the OLS estimator. With the two-stage least squares estimator, we also examine whether IFI's influence on growth depends on other economic, institutional, and policy conditions. That is, we use also interaction terms in the instrumental variable regressions.

We use two sets of instrumental variables. First, we use exogenous indicators that past studies have shown are good predictors of "policy openness" (broadly defined). Specifically, La Porta, Lopez-de-Silanes, Shleifer, and Vishny (1999) show that legal traditions differ in terms of the priority they attach to private property rights relative to the power of the state and that legal systems that emphasize the power of the state tend to be less open to competition. According to this view, the English common law evolved to protect private property owners against the crown. This facilitated the ability of private property owners to transact confidently, with positive repercussions on free, competitive markets. In contrast the French and German civil codes in the $19^{\text {th }}$ century were constructed to solidify State power. Over time, State dominance produced legal traditions that focus more on the power of the State and less on the rights of individual investors. Countries with a socialist legal tradition further reflect these differences. As documented by La Porta et al. (1999), socialist legal origin countries tend to restrict open, competitive markets. According to the La Porta et al (1999) theory, these legal traditions spread throughout the world through conquest, colonization, and imitation, so differences in legal origin can be treated as relatively exogenous. There are five possible legal origins: English Common Law, French Civil Law, German Civil Law, Scandinavian Civil Code, and Socialist/Communist law. Thus, we include dummy variables for 
each country's legal origin (except the Scandinavian law countries) as instrumental variables.

Second, leading economists, historians, and bio-geographers emphasize the impact of geography on economic institutions and policies (e.g., Engerman and Sokoloff, 1997). Lands with high rates of disease and poor agricultural yields - such as the tropics - tend to create political institutions that are closed to competition and free markets so that the elite can exploit the rest of the population (See, Acemoglu, Johnson, and Robinson, 2001; Easterly and Levine, 2002). In contrast, countries with better geographical endowments tend to create political institutions that place greater emphasis on private property rights and competitive markets in part because the elite benefit more from free markets than from limiting competition and exploiting domestic labor. We use the absolute value of latitudinal distance from the equator as an additional instrument in the two-stage least squares regressions.

\section{Motivation for the Dynamic Panel Model}

The dynamic panel approach offers advantages to OLS and also improves on previous efforts to examine the IFI-growth link using panel procedures. First, estimation using panel data -that is pooled cross-section and time-series data - allows us to exploit the time-series nature of the relationship between IFI and growth. Second, in a pure cross-country instrumental variable regression, any unobserved country-specific effect becomes part of the error term, which may bias the coefficient estimates as we explain in detail below. Our panel procedures control for countryspecific effects. Third, unlike existing cross-country studies, our panel estimator (a) controls for the potential endogeneity of all explanatory variables and (b) accounts explicitly for the biases induced by including initial real per capita GDP in the growth regression. Thus, the dynamic panel estimator is free from some of the biases plaguing past studies of IFI and growth. 


\section{Detailed Presentation of the Econometric Methodology}

We use the Generalized-Method-of-Moments (GMM) estimators developed for dynamic panel data that were introduced by Holtz-Eakin, Newey, and Rosen (1990), Arellano and Bond (1991), and Arellano and Bover (1995). Our panel consists of data for a maximum of 57 countries over the period 1976-2000. We average data over non-overlapping, five-year periods, so that data permitting there are five observations per country $(1976-1980,1981-1985, \ldots, 1996-2000) .{ }^{5}$ The subscript "t" designates one of these five-year averages. Consider the following regression equation,

$$
y_{i, t}-y_{i, t-1}=(\alpha-1) y_{i, t-1}+\beta^{\prime} X_{i, t}+\eta_{i}+\varepsilon_{i, t}
$$

where $\mathrm{y}$ is the logarithm of real per capita GDP, $\mathrm{X}$ represents the set of explanatory variables (other

than lagged per capita GDP), $\eta$ is an unobserved country-specific effect, $\varepsilon$ is the error term, and the subscripts $i$ and $t$ represent country and time period, respectively. Specifically, $X$ includes an IFI indicator as well as other possible growth determinants. We also use time dummies to account for period-specific effects, though these are omitted from the equations in the text. We can rewrite equation (2).

$$
y_{i, t}=\alpha y_{i, t-1}+\beta^{\prime} X_{i, t}+\eta_{i}+\varepsilon_{i, t}
$$

To eliminate the country-specific effect, take first-differences of equation (3).

$$
y_{i, t}-y_{i, t-1}=\alpha\left(y_{i, t-1}-y_{i, t-2}\right)+\beta^{\prime}\left(X_{i, t}-X_{i, t-1}\right)+\left(\varepsilon_{i, t}-\varepsilon_{i, t-1}\right)
$$

\footnotetext{
${ }^{5}$ For each five-year period, we require that a country has three years of non-missing data for that variable or the variable is set to missing. We include the early period in the panel estimation, 19761980 , which is excluded from the pure cross-section results, because we need as many time periods as possible to have confidence in the dynamic panel estimation. For this initial period, about 25 percent of the countries have missing data.
} 
The use of instruments is required to deal with (1) the endogeneity of the explanatory variables, and, (2) the problem that by construction the new error term $\varepsilon_{i, t}-\varepsilon_{i, t-1}$ is correlated with the lagged dependent variable, $y_{i, t-1}-y_{i, t-2}$. Under the assumptions that (a) the error term is not serially correlated, and (b) the explanatory variables are weakly exogenous (i.e., the explanatory variables are uncorrelated with future realizations of the error term), the GMM dynamic panel estimator uses the following moment conditions:

$$
\begin{aligned}
& E\left[y_{i, t-s} \cdot\left(\varepsilon_{i, t}-\varepsilon_{i, t-1}\right)\right]=0 \quad \text { for } s \geq 2 ; t=3, \ldots, T \\
& E\left[X_{i, t-s} \cdot\left(\varepsilon_{i, t}-\varepsilon_{i, t-1}\right)\right]=0 \quad \text { for } s \geq 2 ; t=3, \ldots, T
\end{aligned}
$$

We refer to the GMM estimator based on these conditions as the difference estimator.

There are, however, conceptual and statistical shortcomings with this difference estimator. Conceptually, we would also like to study the cross-country relationship between financial development and per capita GDP growth, which is eliminated in the difference estimator. Statistically, Alonso-Borrego and Arellano (1996) and Blundell and Bond (1997) show that when the explanatory variables are persistent over time, lagged levels make weak instruments for the regression equation in differences. Instrument weakness influences the asymptotic and smallsample performance of the difference estimator. Asymptotically, the variance of the coefficients rises. In small samples, weak instruments can bias the coefficients.

To reduce the potential biases and imprecision associated with the usual estimator, we use a new estimator that combines in a system the regression in differences with the regression in levels [Arellano and Bover's 1995 and Blundell and Bond 1997]. The instruments for the regression in differences are the same as above. The instruments for the regression in levels are the lagged differences of the corresponding variables. These are appropriate instruments under the following additional assumption: although there may be correlation between the levels of the right-hand side 
variables and the country-specific effect in equation (3), there is no correlation between the differences of these variables and the country-specific effect, i.e.,

$$
\begin{aligned}
& E\left[y_{i, t+p} \cdot \eta_{i}\right]=E\left[y_{i, t+q} \cdot \eta_{i}\right] \\
& \text { and } E\left[X_{i, t+p} \cdot \eta_{i}\right]=E\left[X_{i, t+q} \cdot \eta_{i}\right] \text { for all } p \text { and } q
\end{aligned}
$$

The additional moment conditions for the second part of the system (the regression in levels) are:

$$
\begin{aligned}
& E\left[\left(y_{i, t-s}-y_{i, t-s-1}\right) \cdot\left(\eta_{i}+\varepsilon_{i, t}\right)\right]=0 \quad \text { for } s=1 \\
& E\left[\left(X_{i, t-s}-X_{i, t-s-1}\right) \cdot\left(\eta_{i}+\varepsilon_{i, t}\right)\right]=0 \quad \text { for } s=1
\end{aligned}
$$

Thus, we use the moment conditions presented in equations (4), (5), (7), and (8), use instruments lagged two period (t-2), and employ a GMM procedure to generate consistent and efficient parameter estimates. ${ }^{6,7}$

Consistency of the GMM estimator depends on the validity of the instruments. To address this issue we consider two specification tests suggested by Arellano and Bond (1991), Arellano and Bover (1995), and Blundell and Bond (1997). The first is a Sargan test of over-identifying

\footnotetext{
${ }^{6}$ We use a variant of the standard two-step system estimator that controls for heteroskedasticity. Typically, the system estimator treats the moment conditions as applying to a particular time period. This provides for a more flexible variance-covariance structure of the moment conditions because the variance for a given moment condition is not assumed to be the same across time. This approach has the drawback that the number of overidentifying conditions increases dramatically as the number of time periods increases. Consequently, this typical two-step estimator tends to induce over-fitting and potentially biased standard errors, which is particularly important for this paper because of data limitations. To limit the number of overidentifying conditions, we follow Calderon, Chong and Loayza (2000) and apply each moment condition to all available periods. This reduces the over-fitting bias of the two-step estimator. However, applying this modified estimator reduces the number of periods by one. While in the standard estimator time dummies and the constant are used as instruments for the second period, this modified estimator does not allow the use of the first and second period. We confirm the results using the standard system estimator.

${ }^{7}$ Recall that we assume that the explanatory variables are "weakly exogenous." This means they can be affected by current and past realizations of the growth rate but not future realizations of the error term. Weak exogeneity does not mean that agents do not take into account expected future growth in their decision to undertake IFI; it just means that unanticipated shocks to future growth do not influence current IFI. We statistically assess the validity of this assumption.
} 
restrictions, which tests the overall validity of the instruments by analyzing the sample analog of the moment conditions used in the estimation process. The second test examines the hypothesis that the error term $\varepsilon_{i, t}$ is not serially correlated. In both the difference regression and the system difference-level regression we test whether the differenced error term is second-order serially correlated (by construction, the differenced error term is probably first-order serially correlated even if the original error term is not).

\section{Results}

\section{A. International Financial Integration and Economic Growth}

Using the econometric methods outlined above, this section presents regression results concerning the relationship between economic growth and various measures of IFI and also assesses whether the growth-IFI relationship depends on economic, financial, institutional, and policy factors as suggested by some theories.

Table 2 presents the benchmark regression without any IFI proxies. Specifically, the regressions simply include the logarithm of initial real per capita GDP, the logarithm of initial schooling, the average government fiscal balance over the period, and the average inflation rate over the period. We present the OLS, instrumental variables (one observation per country) and the GMM system panel estimator (five observations per country) regressions.

The Table 2 OLS results are consistent with previous cross-country growth regressions. The logarithm of initial income enters significantly and negatively, which is evidence of conditional convergence. We also find that the logarithm of initial schooling is significant and positive, suggesting a positive relationship between educational attainment of the workforce and future economic growth. The macroeconomic policy indicators, the government balance and inflation 
enter with the expected signs. While fiscal surplus and inflation enter the growth equation jointly significantly, neither enters individually significantly in the OLS regression; it is difficult to identify the independent impact of the fiscal surplus and the rate of inflation on economic growth.

The benchmark regression results are broadly consistent across the three econometric methodologies. The two-stage least squares regression results produce the same sign as the OLS regressions. While the logarithm of initial income and the logarithm of initial schooling do not enter with t-statistics greater than two, inflation is negatively and significantly related to growth in the two-stage least squares regression.

The system panel estimates further confirm the OLS regressions. The logarithm of initial income and schooling enter significantly and with the same sign as the OLS regressions. The panel estimates also suggest a significant, negative relationship between inflation and economic growth. Unfortunately, when we move to the panel estimator, we lose country observations because some of the countries do not have sufficient data continuously over the entire 1976-2000 period. We have 40 countries in the Table 2 regression. Importantly, however, the panel estimates pass the specifications tests defined above. The Sargan test has a p-value of 0.17 , which means we do not reject the econometric specification and the validity of the instruments. Similarly, the serial correlation test has a p-value of 0.56 , which means we do not reject econometric model due to serial correlation.

Table 3 examines the relationship between economic growth and IFI controlling for the same benchmark regressors presented in Table 2. We present results on five measures: IMFRestriction, the Stock of Capital Flows, Flow of Capital, Stock of Capital Inflows, and Inflow of Capital. As discussed above, we examined the components of these indicators and obtain similar results. Thus, Table 3 summarizes the results of 14 regressions, five regressions each for the OLS 
and two-stage least squares specifications and four regressions for the panel methodology. The reasons there is one less regression for the panel is that we are unable to use the system panel estimator for the IMF-Restriction measure because there is too little cross-time variation in this variable, on average, across the countries and because the IMF-Restriction variable is not available in the last 5-year period, 1996-2000, as discussed above.

Table 3's regressions do not suggest a strong relationship between IFI and economic growth. The IMF-Restriction measure, the Stock of Capital Flows, and the Stock of Capital Inflows are not significantly related to economic growth in any of the regressions. In the OLS regression, the Flow of Capital and Inflow of Capital measures are positively associated with growth. In the two-stage least square regression that controls for the endogeneity of capital flows, however, none of the IFI measures are significantly associated with growth. This suggests that OLS results may be driven by reverse causality. Importantly, the instrumental variables do a good job of explaining cross-country variation in the IFI measures. We reject the null hypothesis that the instruments do not explain the IFI measures at the 0.01 level in all of the two-stage least squares regressions in Table 3.

The panel estimates in Table 3 suggest that there is a not a robust relationship between IFI and economic growth. ${ }^{8}$ There is only one case in which the IFI indicator is significantly associated with growth, i.e., for the indicator of total capital inflows and outflows as a share of GDP. For those that have particularly strong priors that the Flows of Capital indicator is better than the other IFI indicators, these results suggest the IFI exerts a positive influence on economic growth. However, since the IFI-growth relationship is consistent neither across IFI indicators nor across the

\footnotetext{
${ }^{8}$ The four panel regressions in Table 3 pass the standard specifications tests. Specifically, none reject the Sargan test, i.e., they do not reject the econometric specification and the validity of the instruments. Also, the regressions do not exhibit significant serial correlation, i.e., they do not reject the null hypothesis of no serial correlation as discussed in the methodology section.
} 
different estimation procedures, we interpret the econometric results as not strongly rejecting the null hypothesis of no statistical relationship between IFI and economic growth.

\section{B. IFI Under Different Economic, Financial, Institutional, and Policy Environments}

Next, we examine interaction terms to assess whether IFI exerts a positive influence on growth under certain economic, financial, institutional, and policy environment. Specifically, we

first examine whether the growth effects of IFI depend on the level of GDP per capita or the level of educational attainment. Second, we examine whether the growth-IFI relationship depends on the level of financial development, as proxied by banking sector development and stock market development respectively. Third, we test whether IFI's growth impact varies with level of institutional development, as measured by the law and order tradition of the country and the degree of government corruption. Finally, we study the growth-IFI link under different macroeconomic policies, as proxied by inflation and the government fiscal surplus. Thus, as discussed above, we examine the following specification,

$$
\text { GROWTH }=\alpha+\beta I F I+\delta\left[I F I^{*} x\right]+\gamma x+[\text { the benchmark control variables }]+\varepsilon_{\mathrm{i}},
$$

where $\mathrm{x}$ is a variable included in the matrix of control variables $\mathrm{X}$, and is either income per capita, educational attainment, bank development, stock market development, the Rule of Law, government corruption, inflation, or the fiscal balance. In Tables 4-7, we report the estimated coefficients on IFI, the interaction term, and $\mathrm{x}$, i.e., we report statistics on $\beta, \delta$, and $\gamma$. For brevity, we simply present the OLS result because the two-stage least squares and panel regression results are very similar.

Contrary to some theories and past empirical evidence, Table 4 indicates that international financial integration does not exert a positive influence on growth in countries with suitably high levels of GDP per capita or sufficiently high levels of educational attainment. Out of the ten 
regressions in Table 4, only in the regression where we interact Initial Income with the Stock of Capital Flows do we find that IFI and the interaction term enter significantly. However, the results run counter to theory and past findings. In that regression, the results suggest that IFI only promotes growth in sufficiently poor countries, i.e. the growth effect becomes negative as countries become sufficiently rich. In sum, we interpret the Table 4 findings as not rejecting the view that IFI is unrelated to economic growth even when allowing this relationship to vary under different economic conditions, as measured by GDP per capita and educational attainment.

Similarly, Table 5 shows that international financial integration does not exert a positive influence on growth in countries with high levels of bank or stock market development. While banking sector development enters all of the growth regressions positively and significantly (Levine, Loayza, and Beck, 2000), the IFI indicator and the interaction terms between IFI and the financial development indicators never enter significantly. Again, these findings do not show that IFI is unimportant for growth. Rather, the results do not reject the null hypothesis that IFI is unrelated to economic growth even when allowing this relationship to vary with financial development.

We do not find statistical support for the view that the growth effects of international financial integration increase with greater institutional development (Table 6). We examine the Rule of Law and Corruption, where higher values imply greater adherence to the rule of law and

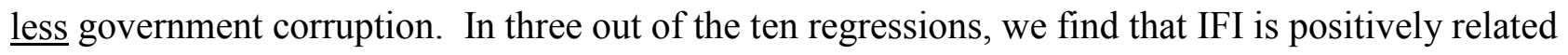
to growth when controlling for institutional development and including interaction terms. However, those regressions the interaction term enters with a sign that runs counter to theoretical predictions. Specifically, the regressions suggest that while IFI is positively related with growth, the positive growth-effects diminish as adherence to the rule of law and the integrity of the government 
increase. Given the infrequency with which the IFI terms enter significantly and the counterintuitive results on the interaction terms in those three regressions, we interpret the results as not rejecting the view that IFI is unrelated to economic growth even when allowing this relationship to vary with institutional development.

Finally, we examine whether the growth-IFI relationship varies with macroeconomic policies. We use inflation and the government fiscal surplus as measures of macroeconomic policies. Again, we do not find strong evidence for the view that IFI has a positive growth effect only in countries with sound macroeconomic policies. IFI enters significantly and positively in only three out of the ten regressions in Table 7 and in these three regressions, the interaction term does not enter significantly. Since we control for macroeconomic policies in the Table 3 regressions (which do not include interaction terms), the Table 7 results do not support the view the IFI boosts growth in general. Turning to the interaction term, the IFI-fiscal balance interaction term does not enter significantly in any of the equations (Table 7). In the inflation regressions, the IFI-inflation term enters significantly in two out of the five regressions. For these equations, the results suggest that IFI in high inflation regimes has a negative growth effect, i.e., IFI is particularly conducive to growth in low inflation countries. While these regressions offer some support to the view that the positive growth effects of IFI depend on macroeconomic stability, these findings are not robust across the different measures of IFI.

\section{Conclusions}

This paper uses new data and new econometric techniques to investigate the impact of international financial integration on economic growth and to assess whether the IFI-growth relationship depends on the level of economic development, educational attainment, financial 
development, legal system development, government corruption, and macroeconomic policies. We contribute to the existing literature by (i) using new measures of international financial integration, (ii) examining an extensive array of IFI indicators, (iii) employing econometric methods that cope with statistical biases plaguing past studies of the IFI-growth relationship, and (iv) investigating, as suggested by some theories, whether IFI only has positive growth effects under particular economic, financial, institutional, and policy regimes. In studying the IFI-growth relationship, the paper examines up to 57 countries over the last 20-25 years using an assortment of statistical methodologies.

The data do not support the view that international financial integration per se accelerates economic growth even when controlling for particular economic, financial, institutional, and policy characteristics. Note, however, these results do not imply that openness is unassociated with economic success. Indeed, IFI is positively associated with real per capita GDP, educational attainment, banking sector development, stock market development, the law and order tradition of the country, and government integrity (low levels of government corruption). Thus, successful countries are generally open economies. Rather, this paper finds that IFI is not robustly linked with economic growth when using a variety of IFI measures and an assortment of econometric approaches. Similarly, although there are isolated exceptions, we do not reject the null hypothesis that IFI is unrelated to economic growth even when allowing this relationship to vary with economic, financial, institutional, and macroeconomic characteristics.

This paper's findings must be interpreted cautiously. As emphasized in the Introduction, there are extreme barriers to measuring openness to international financial transactions. There are many different types of financial transactions, countries impose a complex array of barriers, and the effectiveness of these barriers varies across countries, time, and type of financial transaction. 
Although we use new measures of IFI that improve upon past measures and although we use a more extensive list of IFI measures than past studies, each of these measures may be criticized for not fully distinguishing international differences in barriers to financial transactions. Given these qualifications, this paper finds that although international financial integration is associated with economic success (high levels of GDP per capita and strong institutions), the data do not lend much support to the view that international financial integration stimulates economic growth. 


\section{Acknowledgements}

The authors wish to thank Tamim Bayoumi, Michael Klein, Phillip Lane, Gian Maria MilesiFerreti, and David Robinson for data and helpful comments and Yutong Li and Bennett Sutton for efficient research assistance. The views expressed in this paper are those of the authors and do not necessarily represent those of the IMF or IMF policy. This research was originally conducted as a background paper for Chapter 4 of the October 2001 IMF World Economic Outlook. 


\section{References}

Acemoglu, D., S. Johnson, and J. Robinson, 2001. "The colonial origins of comparative development: an empirical investigation," American Economic Review, 91,1369-1401.

Acemoglu, D., F. Zilibotti, 1997, "Was Prometheus Unbound by chance? Risk Diversification, and Growth," Journal of Political Economy, 105, 709-51.

Alfaro, L., A. Chanda, S. Kalemli-Ozcan, and S.n Sayek. "FDI and Economic Growth: The Role of Local Financial Markets." Harvard Business School, Working Paper, 2001, Number 83.

Alonso-Borrego, C. and M.Arellano. "Symmetrically Normalised Instrumental Variable Estimation Using Panel Data," CEMFI Working Paper No. 9612, September 1996.

Arellano, M. and S. Bond. "Some Tests of Specification for Panel Data: Monte Carlo Evidence and an Application to Employment Equations," Review of Economic Studies 1991, 58, pp. 277297.

Arellano, M., and O. Bover. "Another Look at the Instrumental-Variable Estimation of ErrorComponents Models," Journal of Econometrics 1995, 68, pp. 29-52.

Arteta, C., B. Eichengreen, and C. Wyplosz, 2001, "On the Growth Effects of Capital Account Liberalization," (unpublished; Berkeley: University of California)

Barro, R. J. and J. Lee. "International Measures of Schooling Years and Schooling Quality", AER Papers and Proceedings 1996, $\underline{86}$, pp. 218-223.

Beck, T., and R. Levine, 2002, "Stock Market, Banks, and Economic Growth: Cross-Country and Panel Evidence," University of Minnesota, mimeo.

Bekaert, G., C. R. Harvey, and C. Lundblad, 2001, "Does Financial Liberalization Spur Growth?" NBER Working Paper No. 8245 (Cambridge, Mass.: National Bureau of Economic Research).

Blomstrom, M., Lipsey, R. and M. Zejan, 1994, "What Explains Growth in Developing Countries?," National Bureau of Economic Research Working Paper, No. 5057.

Blundell, R. and S. Bond. "Initial Conditions and Moment Restrictions in Dynamic Panel Data Models," Journal of Econometrics, 1998, 87, pp. 115-43.

Borensztein, E., De Gregorio, J., and J.W. Lee, 1998, How Does Foreign Investment Affect Growth? Journal of International Economics, 45.

Boyd, J. H., and B. D. Smith, 1992, "Intermediation and the Equilibrium Allocation of Investment Capital: Implications for Economic Development," Journal of Monetary Economics, 30, 409-432. 
Calderon, C.; A. Chong, and N. Loayza. "Determinants of Current Account Deficits in Developing Countries," World Bank Research Policy Working Paper 2398, July 2000.

Carkovic, M. and R. Levine, 2002, Does Foreign Direct Investment Accelerate Economic Growth?" University of Minnesota Carlson School of Management), mimeo.

Cooper, R., 1999, "Should Capital Controls Be Banished?” Brookings Papers on Economic Activity, $1,89-141$.

Easterly, W. and R. Levine, 2002, Tropics, germs, and crops. University of Minnesota, mimeo.

Edison, H., M. Klein., L. Ricci, and T. Sløk, 2002, "Capital Account Liberalization and Economic Performance: Survey and Synthesis,” IMF Working Paper No 02/120, (Washington: International Monetary Fund).

Edwards, S., 2001, "Capital Mobility and Economic Performance: Are Emerging Economies Different?” NBER Working Paper No. 8076 (Cambridge, Mass.: National Bureau of Economic Research).

Eichengreen, B., 2001, "Capital Account Liberalization: What do Cross-Country Studies Tell Us?" (unpublished; Berkeley: University of California).

Engerman, S. and K. Sokoloff, 1997, "Factor endowments, institutions, and differential paths of growth among new world economies," In Haber, Stephen (Ed.), How Latin America Fell Behind, Stanford University Press, Stanford CA, pp. 260-304.

Grilli, V. and G. Maria Milesi-Ferreti, 1995, "Economic Effects and Structural Determinants of Capital Controls," Staff Papers, Vol. 42 (September), pp. 517-51.

Henry, P., 2000a, "Stock Market Liberalization, Economic Reform, and Emerging Market Equity Prices," Journal of Finance, Vol. 55 (April), pp. 529-64.

Henry, P., 2000b, “Do Stock Market Liberalizations Cause Investment Booms?” Journal of Financial Economics, 58, 301-334.

Holtz-Eakin, D.; Newey, W, and Rosen, H. "Estimating Vector Autoregressions with Panel Data, “ Econometrica, 1990, $\underline{56}(6)$, pp. 1371-1395.

Klein, M., and G. Olivei, 2000, "Capital Account Liberalization, Financial Depth, and Economic Growth," (unpublished; Somerville, Mass.: Tufts University.

Kraay, A., 1998, "In Search of the Macroeconomic Effects of Capital Account Liberalization," (unpublished; Washington: World Bank). 
Lane, P., and G. Maria Milesi-Ferretti, forthcoming, "The External Wealth of Nations," Journal of International Economics.

La Porta, R., F. Lopez-de-Silanes, A. Shleifer, and R. Vishny, 1999, “The Quality of Government,” Journal of Law, Economics, and Organization, 15, 222-279.

Levine, R., 2001, "International Financial Liberalization and Economic Growth," Review of International Economic, 9, 688-702.

Levine, R., and S. Zervos, 1998a, "Stock Markets, Banks, and Economic Growth," American Economic Review, Vol. 88 (June), 537-58.

Levine, R., and S. Zervos, 1998b, "Capital Control Liberalization and Stock Market Development," World Development, 26, 1169-84.

Levine, R., N. Loayza, and T. Beck, 2000, "Financial Intermediation and Growth: Causality and Causes," Journal of Financial Economics, 46, 31-77.

Levine, R., and D. Renelt, 1992, "A Sensitivity Analysis of Cross-Country Growth Regressions," American Economic Review, Vol. 82 (September), pp. 942-63.

Obstfeld, M., 1994, "Risk-taking, Global Diversification, and Growth," American Economic Review 84, 1310-1329.

Quinn, D., 1997, "The Correlates of Change in International Financial Regulation," American Political Science Review, Vol. 91, (September), pp. 531-51.

Rodrik, D., 1998, "Who Needs Capital-Account Convertibility,” (unpublished; Cambridge, Mass.: Harvard University). 


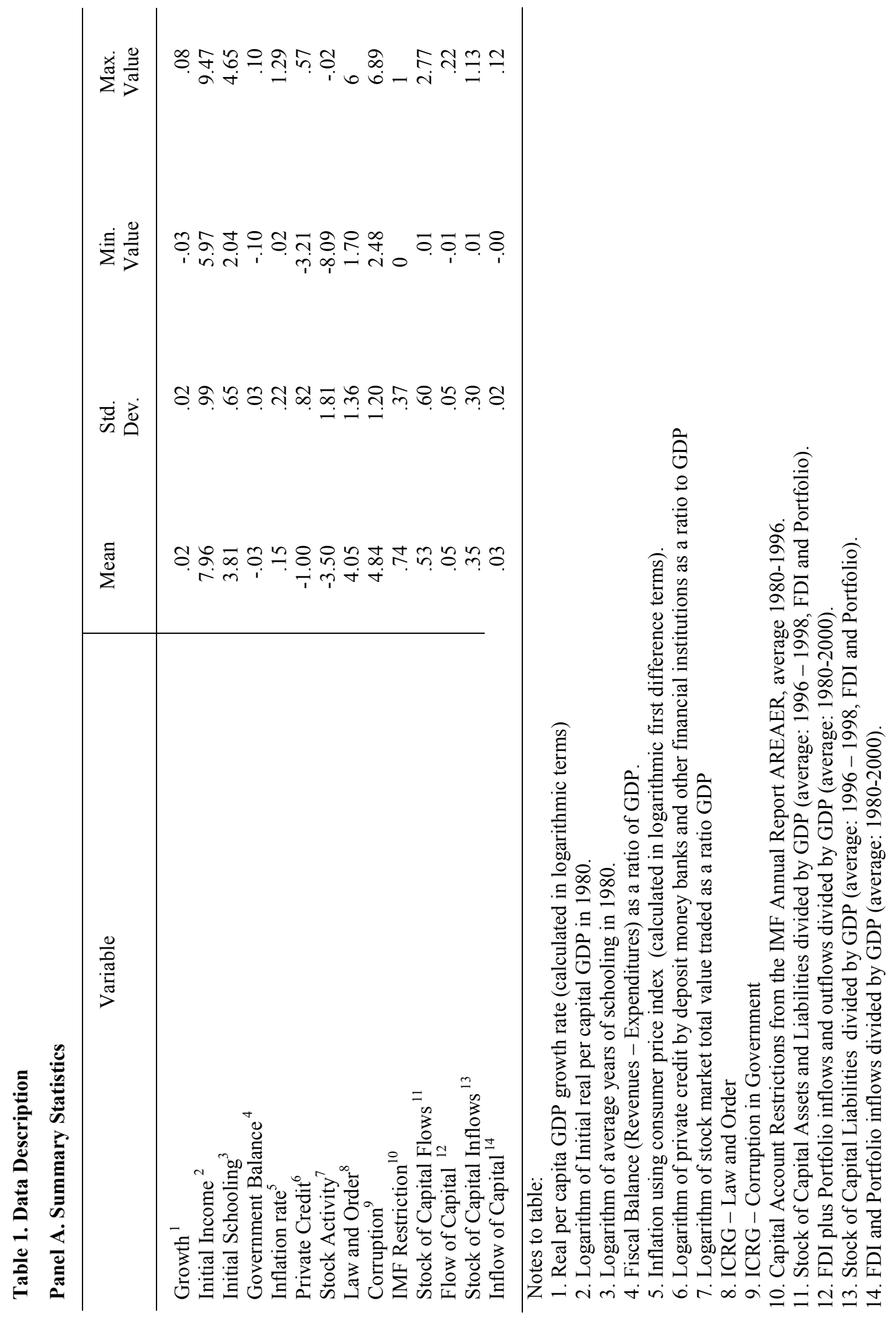




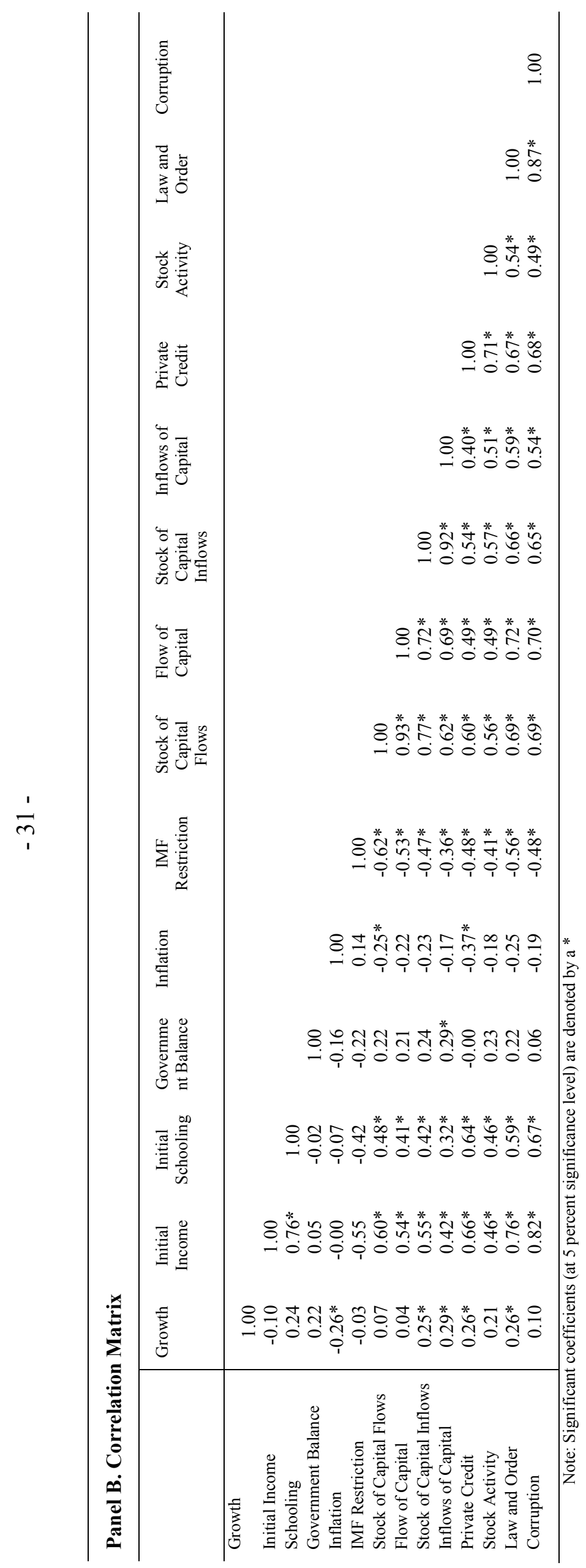



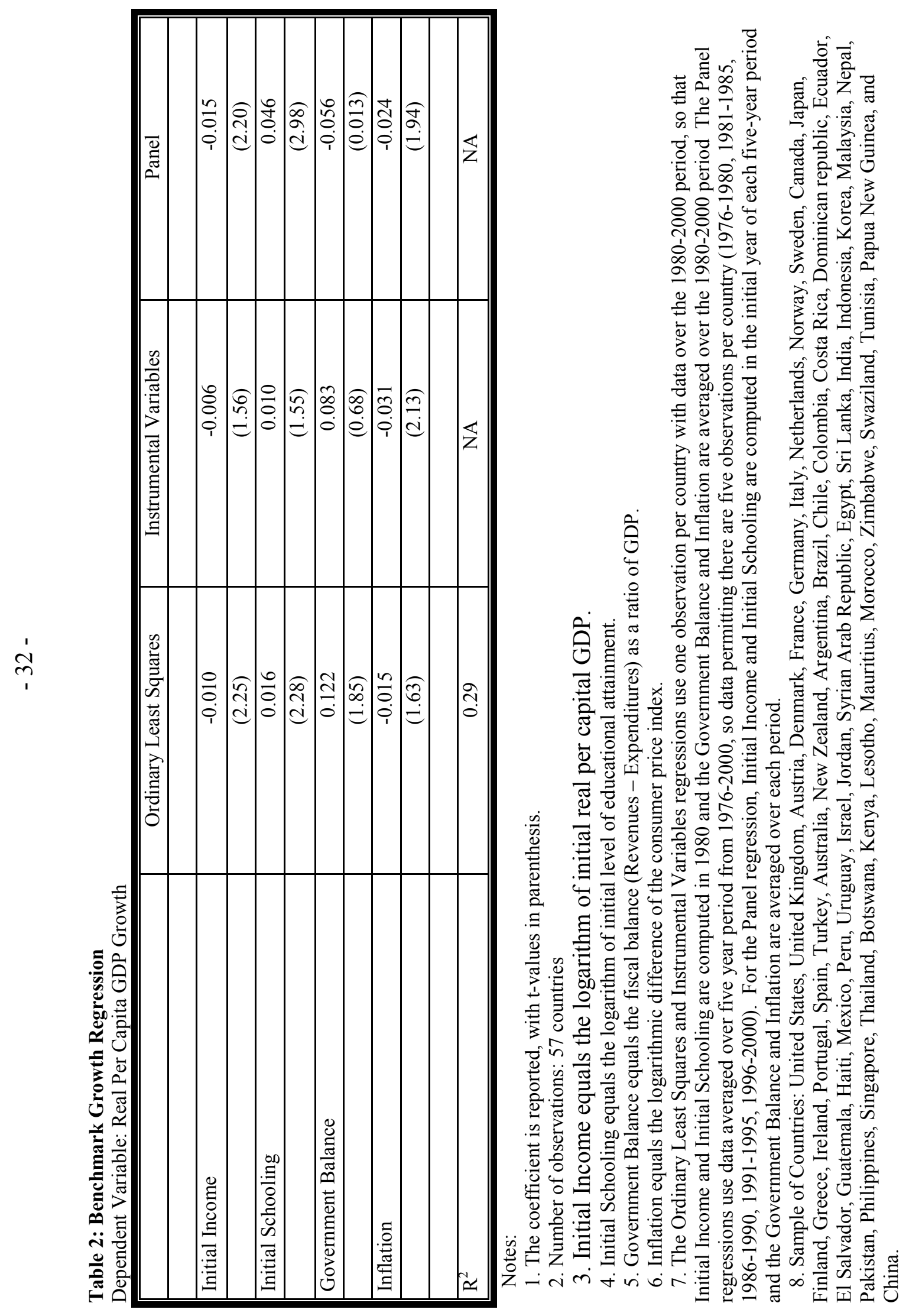


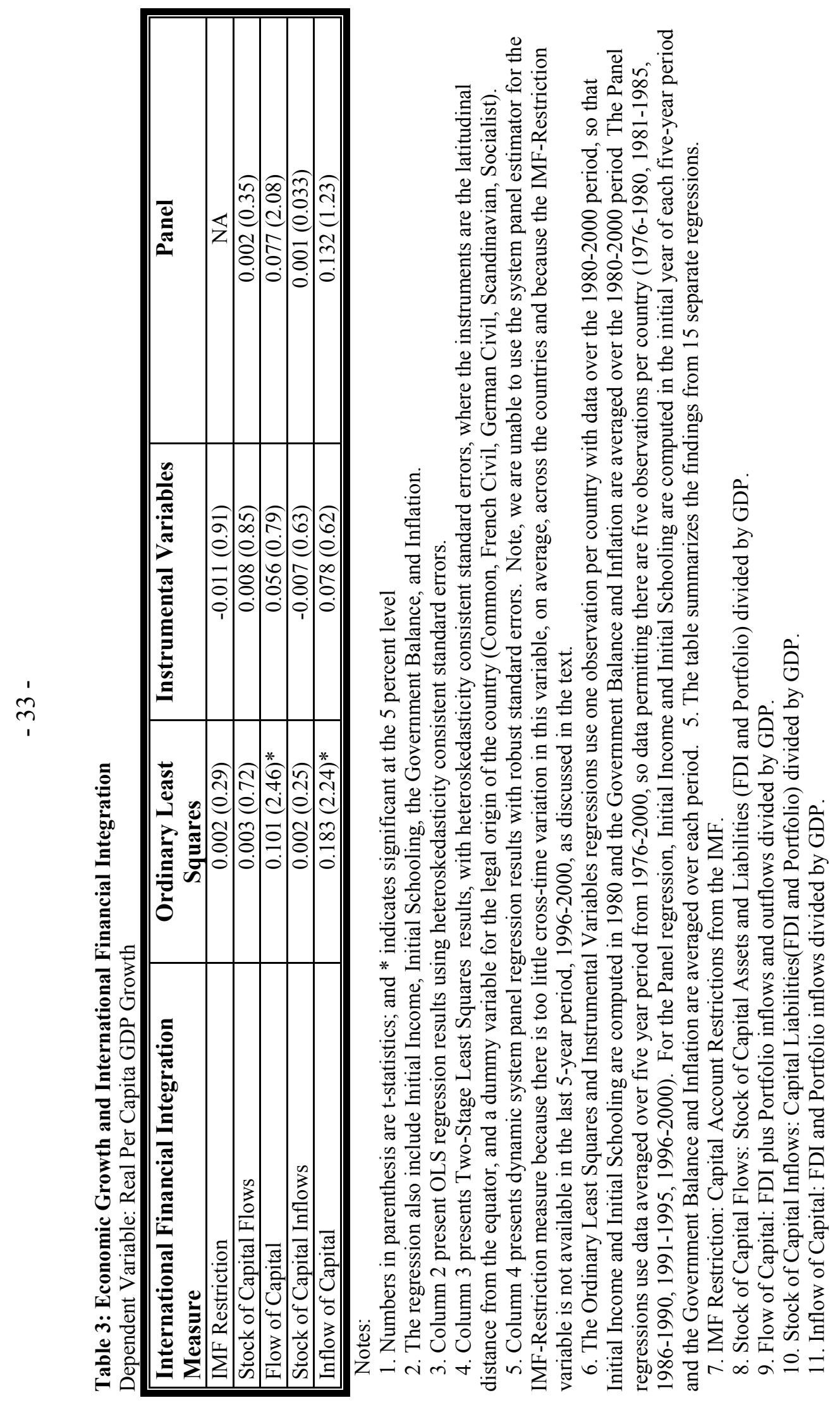



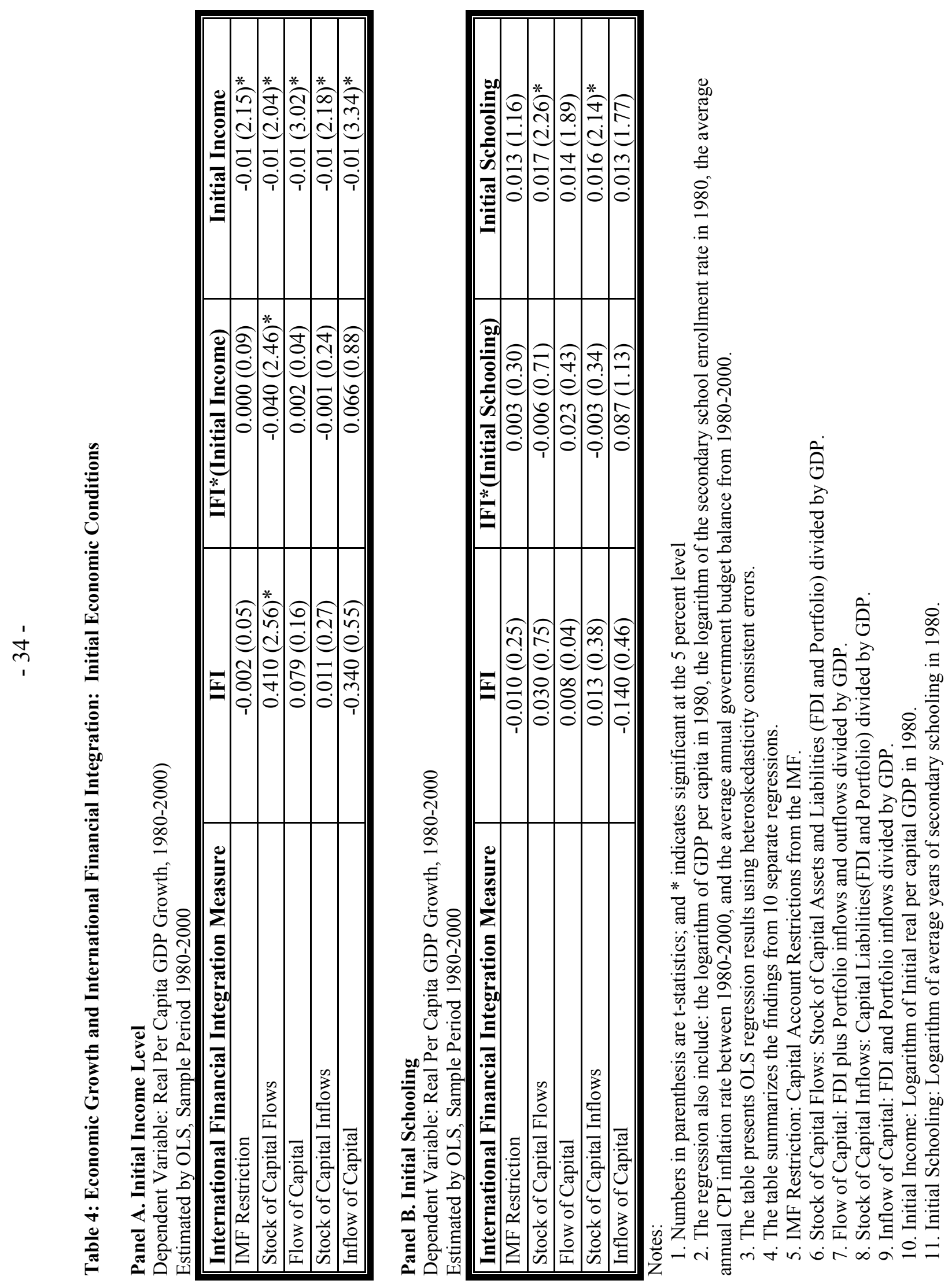

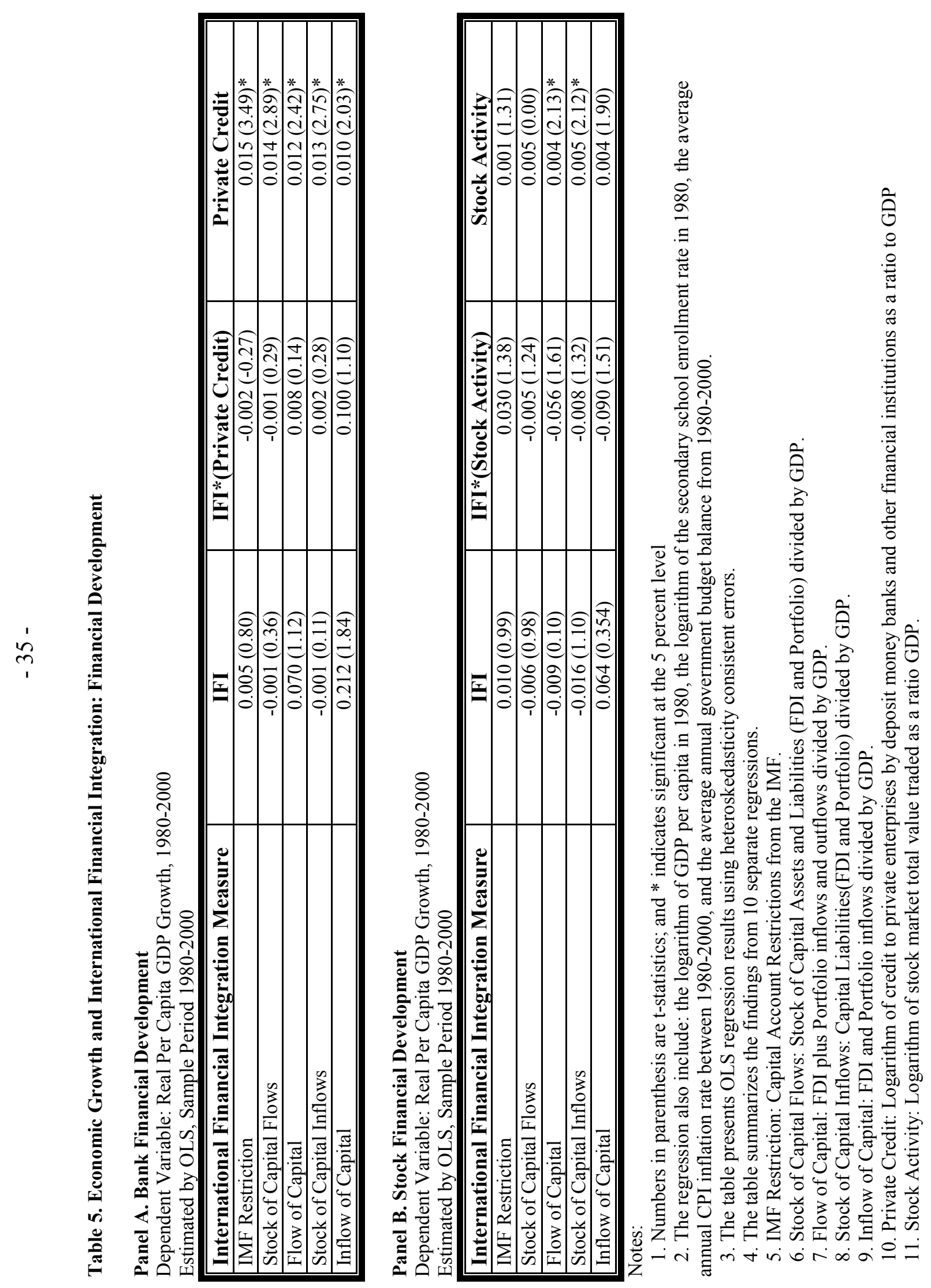

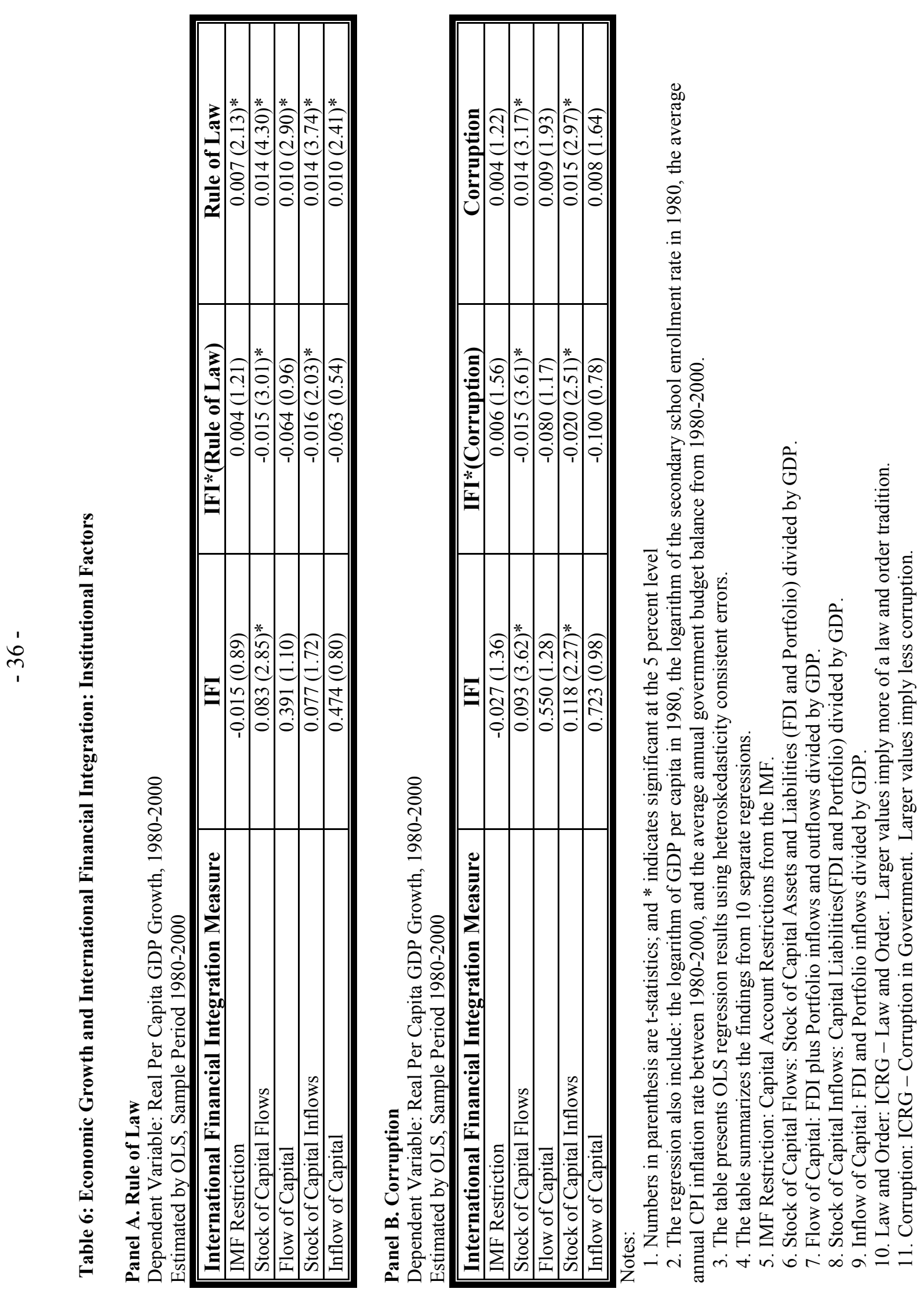

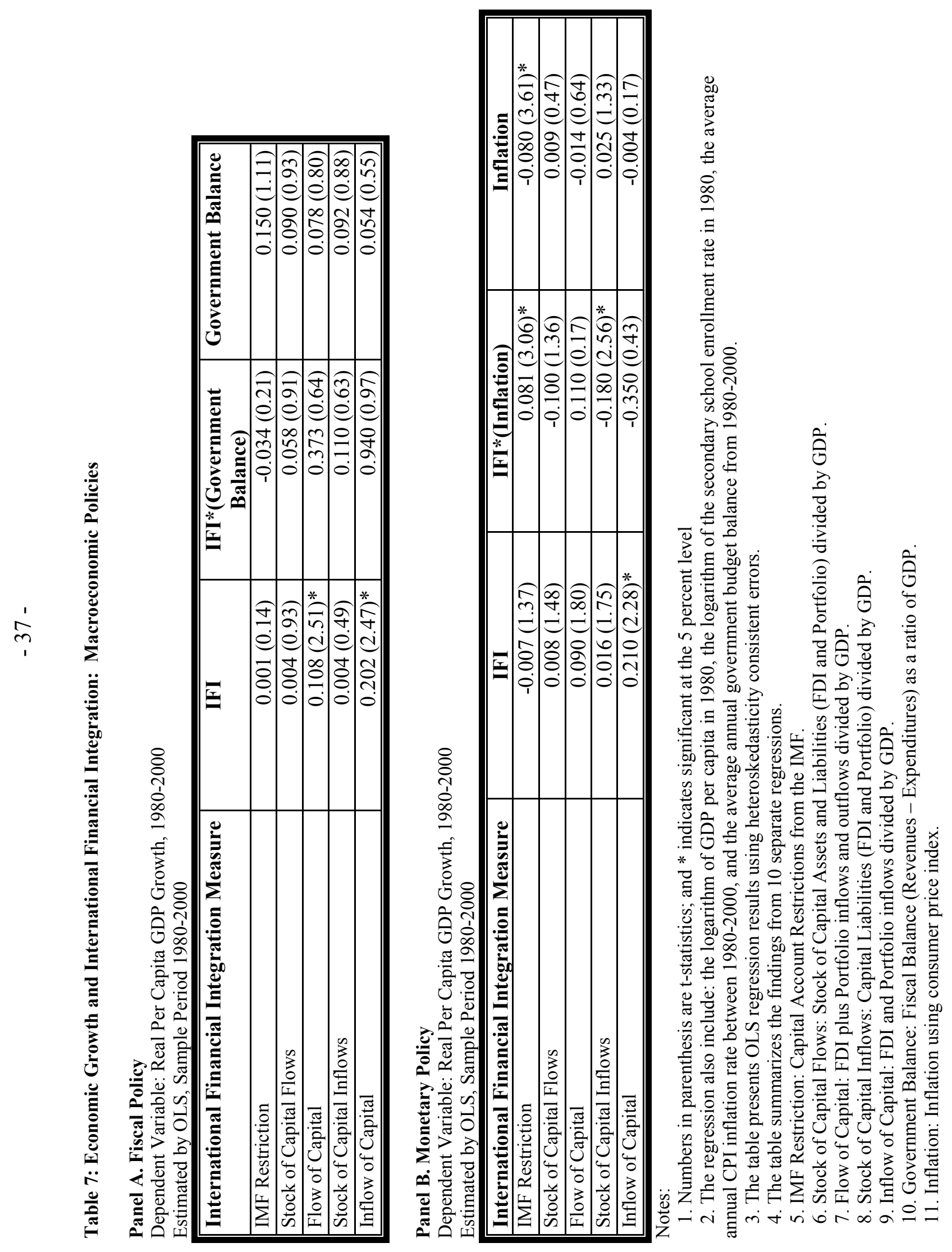


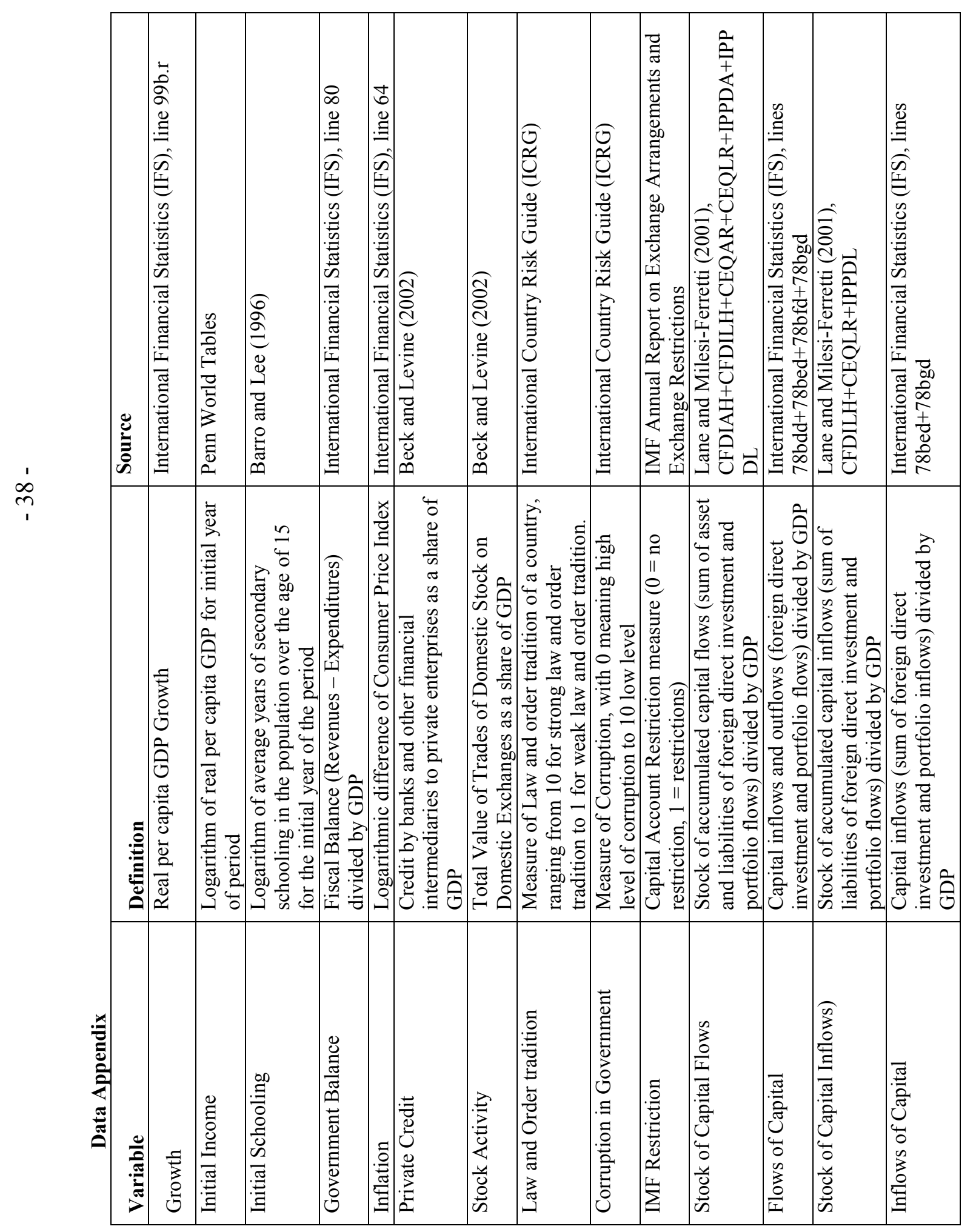

